\title{
Rancang Bangun Sistem Informasi Tender Karet Desa Jungai Menggunakan Metode Waterfall
}

\author{
Fajriyah $^{[1]}$, Ahmat Josi ${ }^{[2]}$, Tolip Fisika ${ }^{[3],}$ \\ Jl. Patra No 50 Kelurahan Sukaraja Kecamatan Prabumulih Selatan, Sumatera Selatan \\ STMIK Prabumulih \\ Rhieyah.stmik@yahoo.com ${ }^{[1]}$,Ahmat_josi@yahoo.com ${ }^{[2]}$,Tolipfisika11@gmail.com ${ }^{[3]}$
}

\begin{abstract}
Abstrak - KUD Mufakat Jaya adalah suatu koperasi unit desa yang mengelola penjualan karet yang beralamat di desa jungai kecamatan rambang kapak tengah kota prabumulih sumatera selatan. Dalam kesehariannya koperasi ini masih menggunakan sistem manual dalam mengolah data dan melakukan sistem tender, sehingga memakan waktu yang lama untuk menyelesaikan proses tender atau lelang harga jual karet. berdasarkan hal tersebut maka peneliti tertarik untuk meningkatkan kualitas pelayanan terhadap masyarakat dengan membangun sebuah sistem informasi tender karet pada KUD Mufakat Jaya
\end{abstract}

Kata Kunci- KUD Mufakat Jaya; karet; tender; Sistem informasi

\section{PENDAHULUAN}

Perkembangan teknologi di era modern saat ini mengalami kemajuan yang sangat pesat, dimana setiap orang dapat menemui berbagi teknologi di berbagai bidang di sekitar kehidupan manusia yaitu salah satunya adalah dengan adanya teknologi informasi [1]. Keberadaan teknologi informasi dapat mempermudah dan mempercepat pengolahan data, teknologi informasi yang sering dimanfaatkan oleh suatu instansi atau organisasi ialah teknologi sistem infomasi. Sistem informasi adalah komponen-komponen yang saling berkaitan yang bekerja bersama-sama untuk mengumpulkan, mengolah, menyimpan, dan menampilkan informasi untuk mendukung pengambilan keputusan, koordinasi, pengaturan, analisa, dan visualisasi pada sebuah organisasi. Pembangunan sistem informasi biasanya didasarkan pada kebutuhan dari suatu perusahaan, instansi maupun suatu unit usaha seperti kud (koperasi unit desa).

Koperasi unit desa (KUD) adalah lembaga pedesaan yang memiliki peran penting dalam pembangunan pertanian [2]. Terutama perekonomian pedesaan. KUD memiliki fungsi perkreditan, penyediaan dan penyaluran sarana-sarana produksi barang-barang keperluan sehari-hari dan jasa-jasa lainnya. KUD memegang peran penting bagi perkembangan perekonomian pedesaan, yaitu sebagai sumber pendapatan, lapangan pekerjaan, dan sebagai pengolahan penjualan suatu desa, misalnya pengolahan tender karet. Tender karet adalah suatu sistem dimana beberapa unit usaha mengajukan penawaran terhadap harga karet dan tawaran tertinggi merupakan pemenang lelang atau tender. Salah satu koperasi yang menggunakan sistem tender untuk penjualan karet ialah KUD Mufakat Jaya.
KUD Mufakat Jaya adalah suatu koperasi unit desa yang mengelola penjualan karet yang beralamat di desa jungai kecamatan rambang kapak tengah kota prabumulih sumatera selatan. Koperasi Mupakat Jaya Kota Prabumulih, pertama di prakarsai oleh beberapa tokoh masyarakat desa Jungai yang di antara lain, Zaman A.Somad, A.Syamsudin, Rusman, Hartoyo dan M.Rilla. Atas inisiatif dari kelima orang tersebut di atas, maka adanya kepercayaan dari masyarakat Desa Jungai, maka pada tanggal 02 april 1988 di Desa jungai di bentuklah sebuah koperasi yang diberi nama Koperasi Unit Desa Mupakat Jaya dengan badan hukum No. 002871/BH/XX/88. Dalam kesehariannya koperasi ini masih menggunakan sistem manual dalam mengolah data dan melakukan sistem tender, berdasarkan hal tersebut maka peneliti tertarik untuk meningkatkan kualitas pelayanan terhadap masyarakat dengan membangun sebuah sistem informasi tender karet pada KUD Mufakat Jaya.

\section{LANDASAN TEORI}

\section{A. Pengertian Rancang Bangun}

Rancang bangun adalah suatu istilah umum untuk membuat atau mendesain suatu objek dari awal pembuatan sampai akhir pembuatan [3].

\section{B. Pengertian Sistem Informasi}

Kombinasi dari teknologi informasi dan aktivitas orang yang menggunakan teknologi itu untuk mendukung operasi dan manajemen. Dalam arti yang sangat luas, istilah sistem informasi yang sering digunakan merujuk kepada interaksi antara orang, proses algoritmik, data, dan teknologi [4] selain itu sistem informasi dapat di artikan suatu organisasi yang mempertemukan kebutuhan pengolahan transaksi harian, mendudkung operasi, bersifat manajerial dan kegiatan strategi dari suatu organisasi dan menyediakan pihak luar tertentu dengan laoran-laporan yang diperlukan [5].

\section{Pengertian Website}

Website atau situs dapat diartikan sebagai kumpulan halaman yang menmpilkan informasi data teks, data gambar diam atau gerak, data animasi,suara,video dan gabungan dari semuanya baik yang bersifat statis maupun dinamis yang membentuk suatu rangkaian bangunan yang saling terkait dimana masing-masing dihubungkan dengan jarngan-jaringan halaman (hyperlink) [6]. 


\section{Metodologi Penelitian}

Metode penelitian Adalah suatu penyelidikan yang sistematis untuk meningkatkan sejumlah pengetahuan, juga merupakan suatu usaha yang sistematis dan terorganisasi untuk menyelidiki masalah tertentu yang memerlukan jawaban. pada dasarnya merupakan cara ilmiah untuk mendapatkan data dengan tujuan dan kegunaan tertentu. Pada penelitian ini penulis menggunakan metode deskriptif kualitatif, deskriptif kualitatif adalah data informasi yang berbentuk kalimat verbal bukan berupa simbol angka atau bilangan [7].

\section{A. Metode Pengumpulan Data}

Metode pengumpulan data terbagi menjadi beberapa bagian yaitu (1).Observasi (Pengamatan). Observasi dilakukan dengan melakukan pengamatan atau peninjauan langsung di KUD Mufakat Jaya Desa Jungai (2). Wawancara (Interview) merupakan proses tanya jawab secara langsung dengan pihakpihak terkait dalam hal ini peneliti melakukan wawancara pada ketua KUD dan beberapa anggota KUD guna mendapatkan informasi yang berkaitan dengan sejarah KUD, sistem tender dan sistem pengelolaan data. (3).Studi Pustaka yaitu pengumpulan data yang bersumber dari berbagai buku yang menjadi referensi, pedoman penulisan riset, penelitian, skripsi atau diktat yang menunjang pemecahan permasalahan yang tidak didapatkan dalam penelitian. (4). Dokumentasi, Teknik dokumentasi digunakan untuk mencari sumber informasi yang ada kaitannya dengan penelitian yang ada, yang berupa dokumen foto dan dokumen KUD. Melalui teknik dokumentasi peneliti dapat mempelajari bahan dokumen yang berhubungan dengan materi sistem informasi tender karet di KUD Mufakat Jaya Desa Jungai.

\section{B. Metode Pengembangan Sistem}

Metode pengembangan sistem yang digunakan dalam penelitian ini ialah metode model air terjutn atau yang sering disebut dengan istilah waterfall ${ }^{[8]}$. ada empat tahapan dalam model waterfall yaitu (1). Analisis (2). Design (3). Coding (3). Testing. Berikut adalah gambaran dari metode waterfall

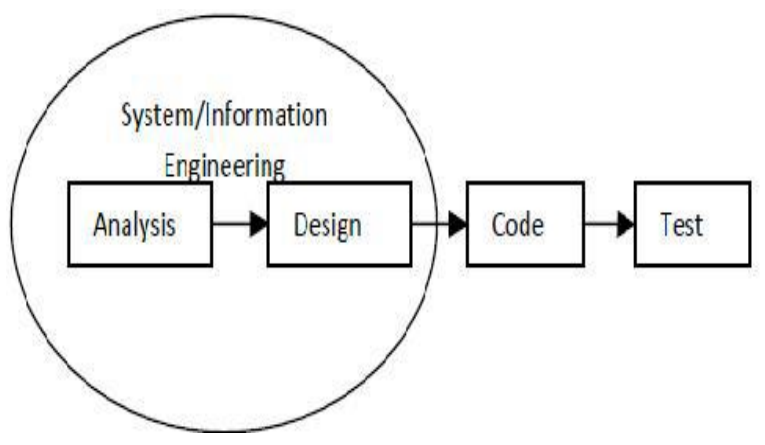

Gambar 1. Model Sekuensial Linear/Waterfall Model

\section{HASIL DAN PEMBAHASAN}

Sesuai dengan metode pengembangan sistem yang digunakan yaitu metode waterfall, maka peneliti melakukan empat tahapan dalam perancangan dan pembangunan sistem informasi tender karet pada KUD Mufakat Jaya desa Jungai, antara lain sebagai berikut:

\section{A. Analisis}

Analisis yang dilakukan terbagi menjadi dua antara lain (1).analisis permasalahan adalah analisis yang dilakukan untuk mengetehui permasalahan yang ada di KUD mufakat jaya desa jungai, berdsarkan hasil analisis dapat diketahui bahwa Sistem penentuan harga tender karet di KUD mufakat jaya masih bersifat secara konvensional Belum ada aplikasi pendukung dalam sistem tender karet. (2). Analisis sistem yaitu analisis yang dilakukan untuk mengetahui sistem yang berjalan pada KUD mufakat Jaya desa jungai dan memberikan solusi terhadap sistem usulan. Berikut gambaran sistem yang berjalan dan sistem usulan pada KUD berkat

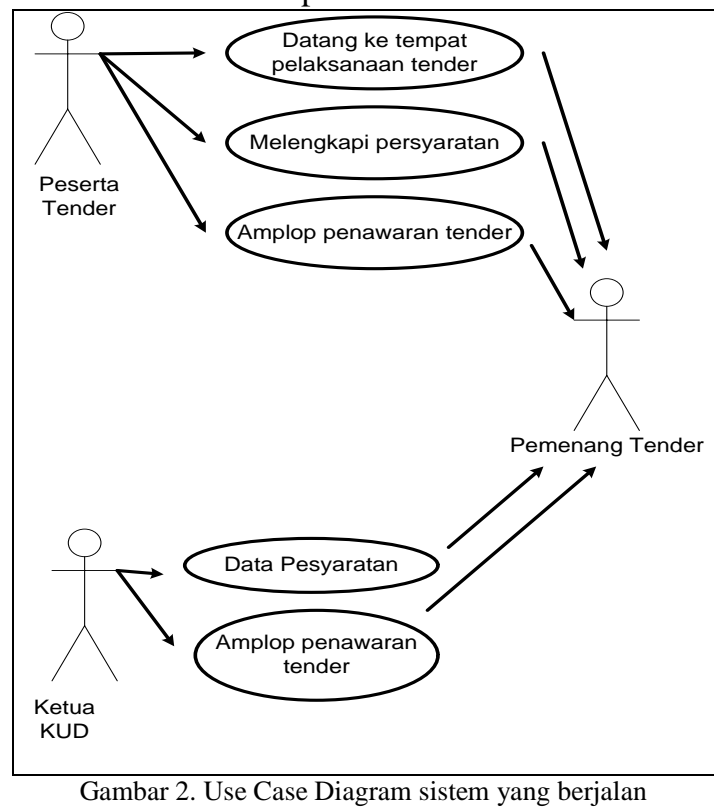

Use case diagram sistem usulan pada KUD mufakat Jaya Desa jungai dapat dilihat pada gambar berikut.

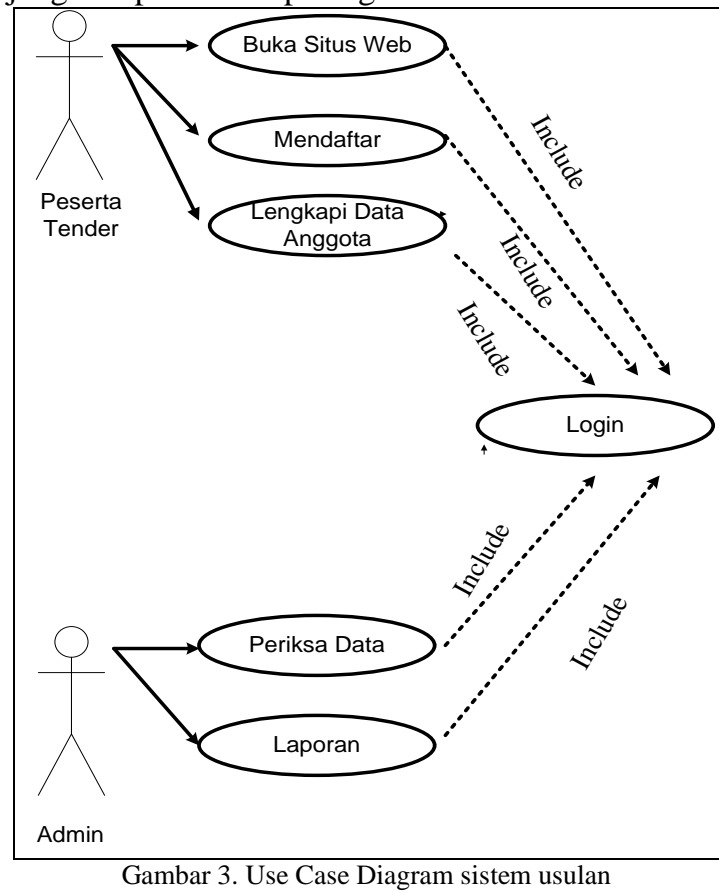




\section{B. Design (Perancangan)}

Desain terbagi menjadi dua yaitu (1). Desain interface (2). Desain database, desain interface dapat dilihat pada gambar berikut ini

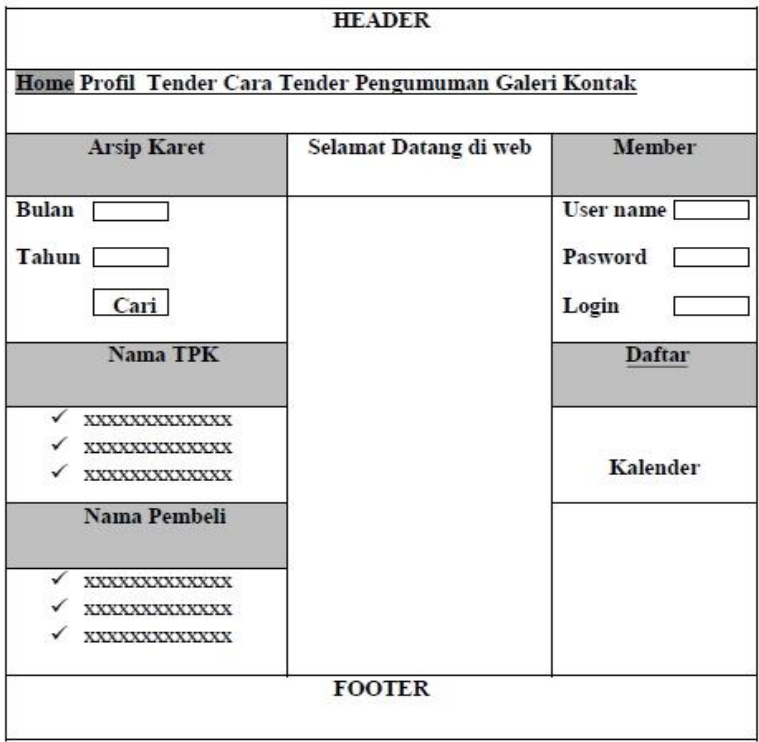

Gambar 4. Rancangan halaman utama

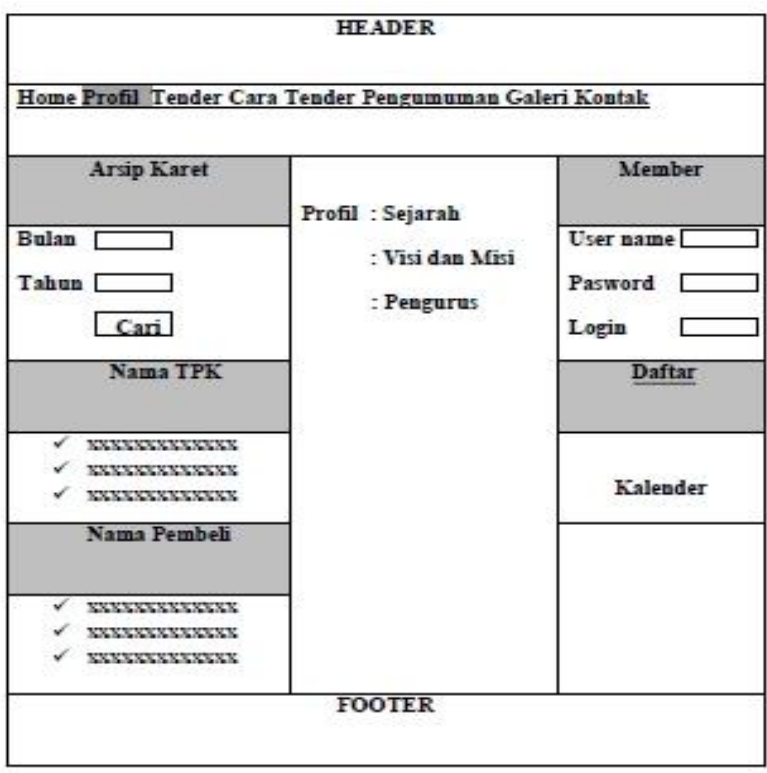

Gambar 5. Rancangan halaman Profil

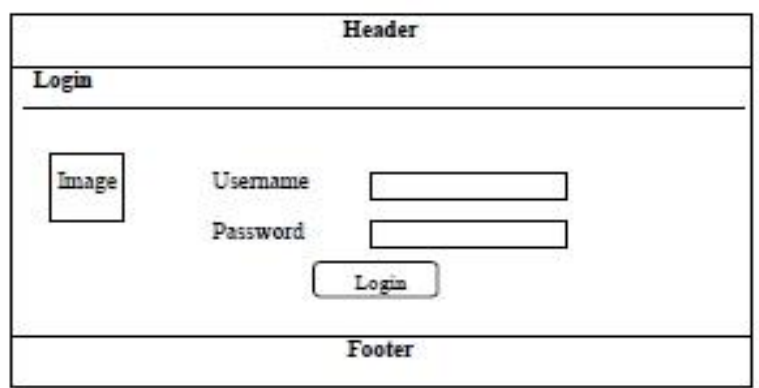

Gambar 6. Rancangan halaman Login Admin

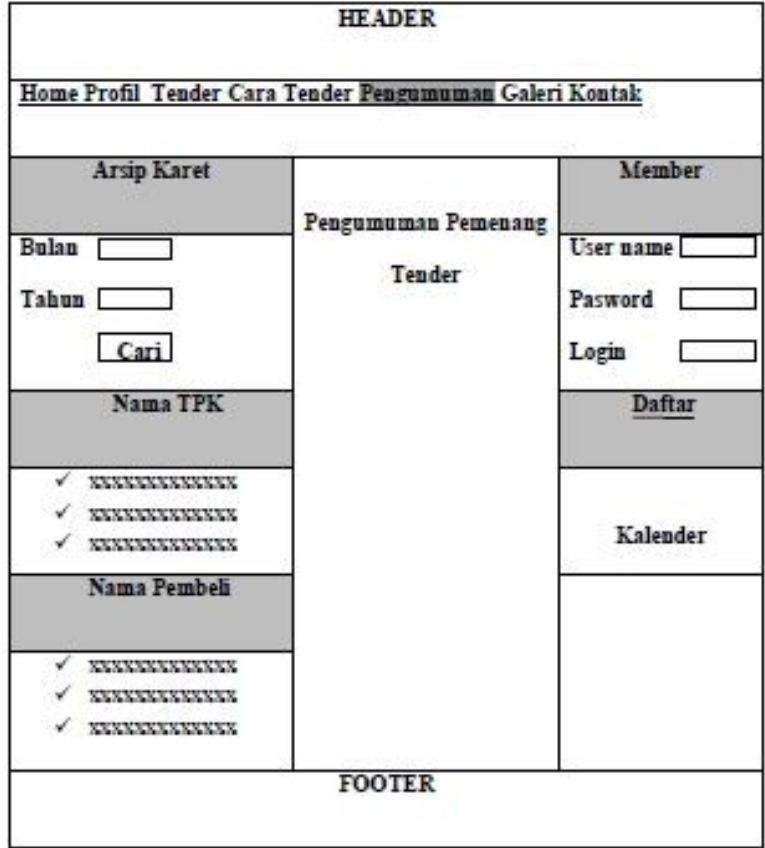

Gambar 5. Rancangan halaman Hasil Pemenang Tender

Desain selanjutnya ialah desain database, berikut adalah beberapa desain database yang akan dibangun untuk sistem informasi kud mufakat jaya.

\begin{tabular}{|c|c|c|}
\hline \multirow{2}{*}{$\begin{array}{c}\text { Tempat } \\
\text { Pengumpulan } \\
\text { Karet (TPK) }\end{array}$} & \multirow{5}{*}{$\begin{array}{l}\text { + Id_karet } \\
\text { + Id_TPK } \\
\text { + Tanggal } \\
\text { + JumlahHarga }\end{array}$} & Data Pembeli \\
\hline & & \multirow{5}{*}{$\begin{array}{l}\text { + Id_Pembeli } \\
\text { + Nama_Pembeli } \\
\text { + Username } \\
\text { + Password } \\
\text { + Alamat } \\
\text { + No_Hp }\end{array}$} \\
\hline + Id_TPK & & \\
\hline + Nama_TPK & & \\
\hline $\begin{array}{l}\text { + Alamat_TPK } \\
+ \text { Ketua_TPK }\end{array}$ & & \\
\hline+ No_Hp & \multirow{2}{*}{$\begin{array}{l}\text { + Ditambah } \\
+ \text { Edit } \\
+ \text { Hapus } \\
\end{array}$} & \\
\hline $\begin{array}{l}\text { + Ditambah } \\
\text { + Edit } \\
\text { + Hapus }\end{array}$ & & $\begin{array}{l}\text { + Dilihat } \\
+ \text { Hapus }\end{array}$ \\
\hline \multirow{3}{*}{$\begin{array}{c}\text { Data } \\
\text { Transaksi } \\
\text { Tender }\end{array}$} & Menu Admin & \multirow[b]{2}{*}{ Data Laporan } \\
\hline & \multirow{5}{*}{$\begin{array}{l}\text { + TPK } \\
\text { + Data Karet } \\
\text { + Data Pembeli } \\
\text { + Data Transaksi } \\
\text { Tender } \\
\text { + Data Laporan } \\
\text { + Data User }\end{array}$} & \\
\hline & & \multirow{3}{*}{$\begin{array}{l}\text { + Id_TPK } \\
\text { + Nama_TPK } \\
\text { + Alamat_TPK } \\
\text { + Ketua_TPK } \\
\text { + No_Hp }\end{array}$} \\
\hline \multirow{3}{*}{$\begin{array}{l}\text { + Id_TPK } \\
\text { + Nama_TPK } \\
\text { + Alamat_TPK } \\
\text { + Ketua_TPK } \\
\text { + No_Hp } \\
\end{array}$} & & \\
\hline & & \\
\hline & & \multirow{2}{*}{ + Dilihat } \\
\hline \multirow[t]{5}{*}{$\begin{array}{l}\text { + Ditambah } \\
\text { + Edit } \\
\text { + Hapus }\end{array}$} & \multirow{2}{*}{$\begin{array}{l}\text { + Mengisi } \\
\text { + Melihat } \\
\text { + Mengecek } \\
\text { + Mengubah } \\
\text { + Menghapus } \\
\end{array}$} & \\
\hline & & Data User \\
\hline & & $\begin{array}{l}\text { + Id_TPK } \\
\text { + Nama_TPK }\end{array}$ \\
\hline & & $\begin{array}{l}\text { + Alamat_TPK } \\
\text { + Ketua_TPK } \\
\text { + No_Hp }\end{array}$ \\
\hline & & $\begin{array}{l}\text { + Ditambah } \\
\text { + Edit } \\
\text { + Hapus }\end{array}$ \\
\hline
\end{tabular}

Gambar 6. Rancangan Database

\section{Coding}

Setelah melakukan analisis dan mendesain sistem, tahapan selanjutnya ialah mengimplementasikan rancangan kedalam 
bentuk aplikasi atau sistem informasi, tahap ini disebit dengan istilah coding, berikut potongan coding sistem informasi tender karet Mufakat Jaya, berikut adalah potongan coding sistem informasi KUD mufakat jaya:

\begin{tabular}{l}
\hline <php \\
include '../include/koneksi.php'; \\
\$id_pembeli=\$_POST['id_pembeli']; \\
\$nama_pembeli=\$_POST['nama']; \\
\$username=\$_POST['username']; \\
\$password=md5(\$_POST['password']); \\
\$alamat=\$_POST['alamat']; \\
\$no_hp=\$_POST['no_hp']; \\
mysql_query("UPDATE pembeli SET \\
nama_pembeli='\$nama_pembeli',username='\$username',p \\
assword='\$password',alamat='\$alamat',no_hp='\$no_hp' \\
WHERE id_pembeli='\$id_pembeli'");
\end{tabular}

\section{Testing}

Dalam testing terbagi menjadi dua yaitu testing interface atau pengujian sistem secara langsung dan testing menggunakan metode yaitu testing dengan metode blac-box ${ }^{[9]}$ dan top down, testing interface dapat dilihat pada gambar berikut ini.

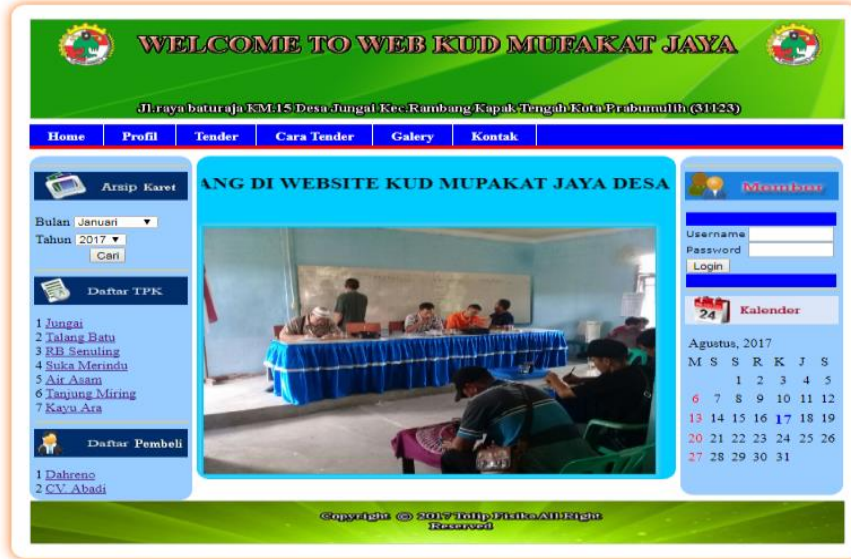

Gambar 7. Halaman utama

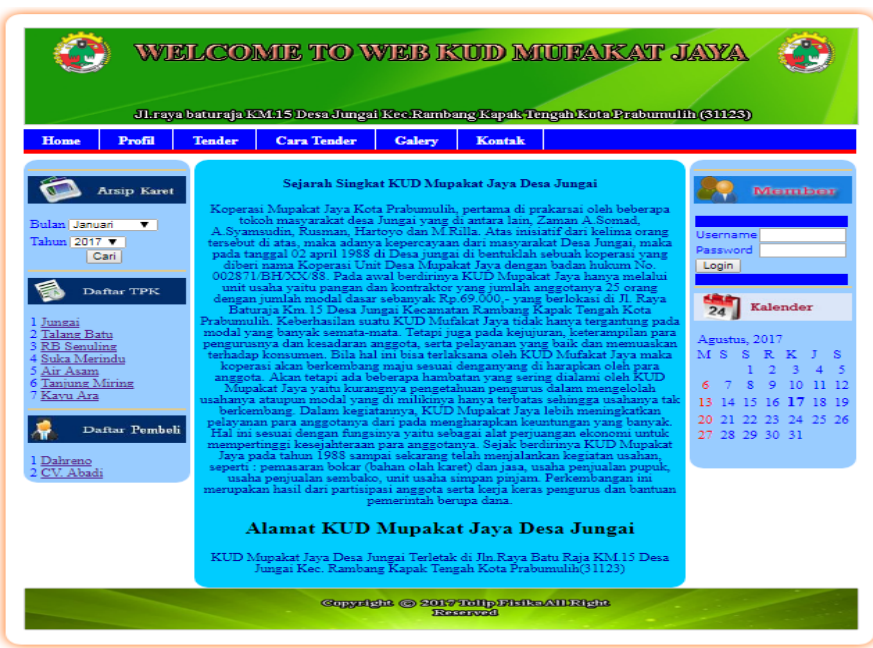

Gambar 8. Halaman Profil

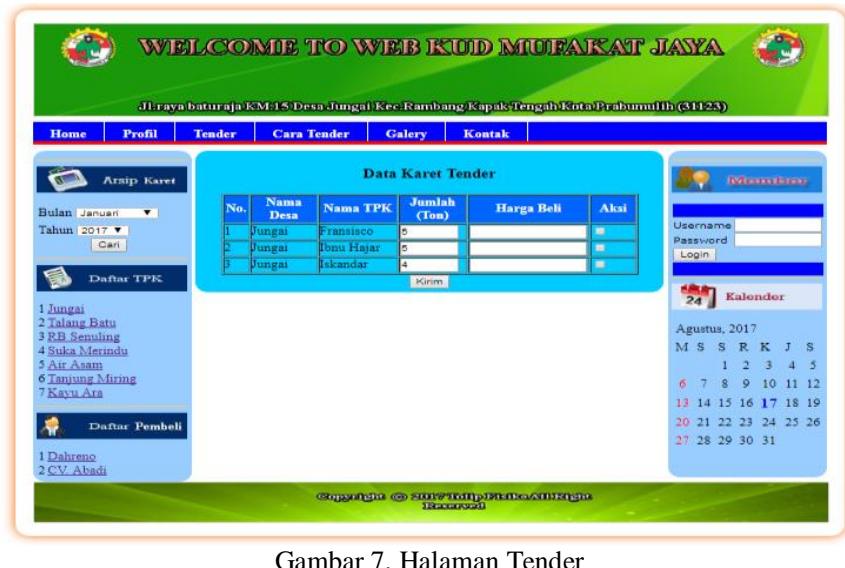

Gambar 7. Halaman Tender

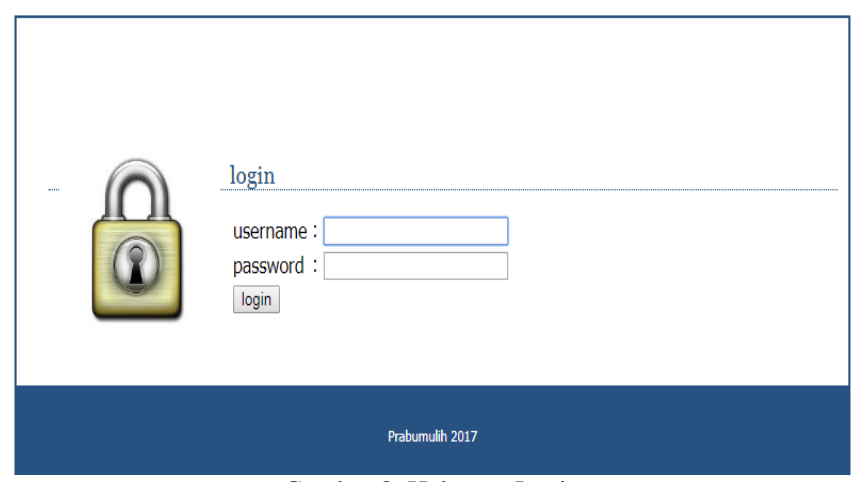

Gambar 8. Halaman Login

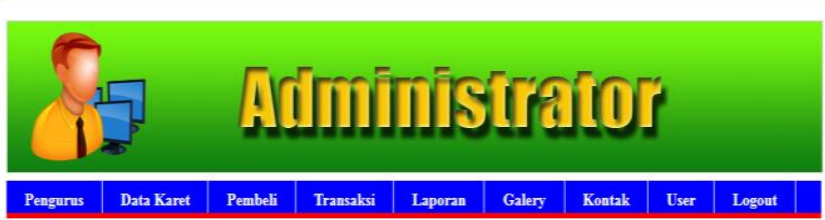

Data Transaksi Tender

Tambah

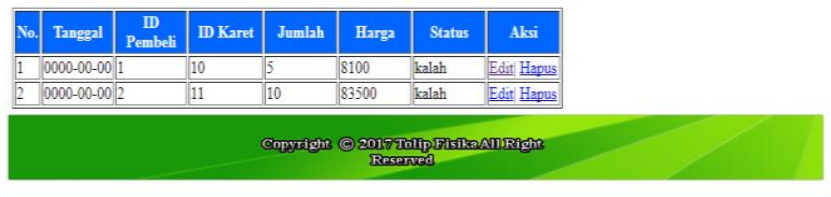

Gambar 9. Pengumuman Lelang

TABel 1. Pengujian Black Box

\begin{tabular}{|c|l|l|l|l|l|}
\hline \multirow{2}{*}{ No } & Fungsi & \multicolumn{1}{c|}{$\begin{array}{c}\text { Cara } \\
\text { yang diuji }\end{array}$} & \multicolumn{1}{c|}{$\begin{array}{c}\text { Hasil yang } \\
\text { Pengujian }\end{array}$} & \multicolumn{2}{|c|}{ Hasil Pengujian } \\
\cline { 4 - 6 } & Login & $\begin{array}{l}\text { Melakukan } \\
\text { Login untuk } \\
\text { masuk } \\
\text { halaman } \\
\text { utama }\end{array}$ & $\begin{array}{l}\text { Menampilkan } \\
\text { form utama }\end{array}$ & Ok & Oser \\
\hline 2 & $\begin{array}{l}\text { Form } \\
\text { utama } \\
\text { Admin }\end{array}$ & $\begin{array}{l}\text { Membuka } \\
\text { form utama } \\
\text { Admin }\end{array}$ & $\begin{array}{l}\text { Menampilkan } \\
\text { daftar menu } \\
\text { dari fasilitas } \\
\text { yang } \\
\text { disediakan } \\
\text { aplikasi }\end{array}$ & & \\
& & & & \\
& & & & & \\
& & & & & \\
\end{tabular}




\begin{tabular}{|c|c|c|c|c|c|}
\hline \multirow{2}{*}{ No } & \multirow{2}{*}{$\begin{array}{c}\text { Fungsi } \\
\text { yang diuji }\end{array}$} & \multirow{2}{*}{$\begin{array}{c}\text { Cara } \\
\text { Pengujian }\end{array}$} & \multirow{2}{*}{$\begin{array}{l}\text { Hasil yang } \\
\text { diharapkan }\end{array}$} & \multicolumn{2}{|c|}{ Hasil Pengujian } \\
\hline & & & & Admin & User \\
\hline 3 & $\begin{array}{l}\text { Tambah } \\
\text { User }\end{array}$ & $\begin{array}{l}\text { Pada form } \\
\text { utama } \\
\text { admin atau } \\
\text { user pilih } \\
\text { manage } \\
\text { user lalu } \\
\text { klik add }\end{array}$ & $\begin{array}{l}\text { Menampilkan } \\
\text { form ntuk } \\
\text { menambah } \\
\text { data user }\end{array}$ & $\mathrm{OK}$ & Ok \\
\hline 4 & Edit User & $\begin{array}{l}\text { Pada form } \\
\text { utama } \\
\text { admin atau } \\
\text { user pilih } \\
\text { manage } \\
\text { user lalu } \\
\text { klik edit }\end{array}$ & $\begin{array}{l}\text { Menampilkan } \\
\text { form ntuk } \\
\text { menambah } \\
\text { data user }\end{array}$ & $\mathrm{OK}$ & Ok \\
\hline 5 & $\begin{array}{l}\text { Hapus } \\
\text { User }\end{array}$ & $\begin{array}{l}\text { Pada form } \\
\text { utama } \\
\text { admin atau } \\
\text { user pilih } \\
\text { manage } \\
\text { user lalu } \\
\text { klik delete }\end{array}$ & $\begin{array}{l}\text { Menghapus } \\
\text { data user }\end{array}$ & OK & Ok \\
\hline 6 & $\begin{array}{l}\text { Tambah } \\
\text { Transaction }\end{array}$ & $\begin{array}{l}\text { Pada form } \\
\text { utama } \\
\text { admin atau } \\
\text { user } \\
\text { pilih } \\
\text { manage } \\
\text { Transaction, } \\
\text { laluklik } \\
\text { add }\end{array}$ & $\begin{array}{l}\text { Menampilkan } \\
\text { Form untuk } \\
\text { menambah } \\
\text { data } \\
\text { Transaction } \\
\text {. }\end{array}$ & $\mathrm{OK}$ & $\mathrm{OK}$ \\
\hline 7 & Log Out & $\begin{array}{l}\text { Pada form } \\
\text { utama } \\
\text { admin atau } \\
\text { user } \\
\text { klik logout }\end{array}$ & 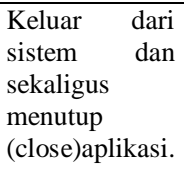 & $\mathrm{OK}$ & OK \\
\hline
\end{tabular}

Pengujian selanjutnya yaitu menggunakan top-down yang dapat dilihat pada table berikut

TABel 2. Pengujian Metode Top DOWN

\begin{tabular}{|ccc|}
\hline \multicolumn{3}{|c|}{ Halaman Utama } \\
\hline L & U & T \\
\hline L1 & U1 & T1 \\
\hline L2 & U 2 & T2 \\
\hline L3 & U3 & T3 \\
\hline Valid & Valid & Valid \\
\hline
\end{tabular}

\section{E. Perbandingan Sistem}

Berdasarkan hasil pengujian tersebut dapat dilihat perbandingan sistem lama dengan cara manual dan sistem yang baru
TABEL 3. PERBANDingan SISTEM

\begin{tabular}{|l|l|l|}
\hline Permasalahan & Sistem lama & Sistem baru \\
\hline Sistem & Manual & Diproses Sistem \\
\hline Analisa Data & $\begin{array}{l}\text { Menganalisa Harga } \\
\text { Tender (Manual) }\end{array}$ & $\begin{array}{l}\text { Analisa data } \\
\text { menggunakan Sistem }\end{array}$ \\
\hline $\begin{array}{l}\text { Proses } \\
\text { Perhitungan } \\
\text { Angka Tender }\end{array}$ & Secara Manual & Secara Otomatis \\
\hline Waktu Proses & 1 Hari- 3 Hari & 2-4 menit \\
\hline $\begin{array}{l}\text { Pengulangan } \\
\text { Hasil } \\
\text { Pemenang } \\
\text { Tender }\end{array}$ & 4-7 kali & $1-2$ kali \\
\hline
\end{tabular}

Berdasarkan hasil pengujian dan perbandingan sistem diatas dapat dilihat gambaran simulasi grafik sistem lama dan sistem yang baru

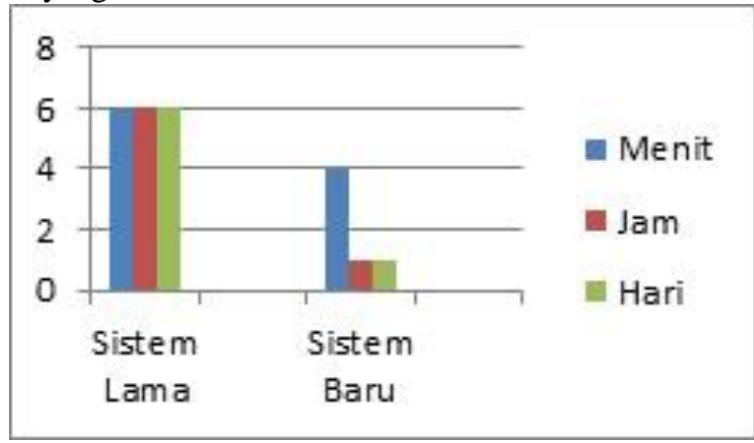

Gambar 10. Simulasi Grafik Perbandingan Sistem

\section{DAFTAR PUSTAKA}

[1] A Josi, 2017. Implementasi Algoritma Genetika Pada Aplikasi Penjadwalan Perkuliahan Berbasis Web Dengan Mengadopsi Model Waterfall (Studi Kasus: STMIK Prabumulih).. Jurnal Informatika:Jurnal Pengembangan IT (JPIT) Vol 2, No 2.

[2] Sulistyo S Purnomo, , Sudjana B, 2010. Pemberdayaan Koperasi Unit Desa Melalui Analisis Faktor-Faktor Kunci Manajemen). Jurnal Agrikultura Vol 21, No 01.

[3] Imam, D., 2016, Rancang Bangun Website Smk Ypn Abadi Prabumulih Dengan Menggunakan Bootstrap, Skripsi, Program Studi Sistem Informasi, Sekolah Tinggi Manajemen Informatika Dan Komputer Prabumulih, Prabumulih.

[4] Tama, NK., 2016, Rancang Bangun Website Program Studi Smk Negeri 2 Prabumulih Menggunakan Framework Bootstrap, Skripsi, Program Studi Sistem Informasi, Sekolah Tinggi Manajemen Informatika Dan Komputer Prabumulih, Prabumulih.

[5] Riyadi, Retnandi E, Deddy A, 2012. Perancangan sistem informasi berbasis website subsistem guru di sekolah pesantren persatuan islam 99 rancabango.. Jurnal Algoritma Vol 09, No 40.

[6] A Josi, 2016. Implementasi Framwork Boostrap pada Website STMIK Prabumulih.. Jurnal Mantik Penusa Vol 20, No 1.

[7] A Josi, 2017. Perancangan Dan Implementasi E-Jurnal Pada Unit Penelitian Dan Pengabdian Masyarakat (Up2m) Stmik Prabumulih. JIPN (Journal of Informatics Pelita Nusantara) Vol 1, No 2.

[8] A Josi, Abdillah LA, Suryayusra, 2014. Penerapan Teknik Web Scraping Pada Mesin Pencari Artikel Ilmiah. Jurnal Sistem Informasi(SISFO) Vol 5, No 2.

[9] Sasmito, G.W.,, 2017. Penerapan Metode Waterfall Pada Desain Sistem Informasi Geografis Industri Kabupaten Tegal. JURNAL INFORMATIKA: Jurnal Pengembangan IT, Vol 2, No 1. 